\title{
1 UK economic outlook: Brexit Britain in Covid recovery ward
}

\author{
by Hande Küçük, Cyrille Lenoël and Rory Macqueen ${ }^{1}$
}

\section{Economic background and recent developments}

One risk materialises while another dissipates.

At the time our last forecast was produced in late October the UK economic recovery faced significant downside risks from a resurgence of Covid-19 and the possibility of a No Deal Brexit.

Failure to control Covid-19 is holding back the economic recovery.

The first of these risks has been realised in the emergence of a major 'second wave' of infections and deaths (see Figure 1.1). Tragically, total number of Covid-19 related deaths have risen to 108,013 as of 2 February 2021, making the UK death rate one of the highest in the world- -162.8 per 100,000 population. The resurgence of the virus has led to a series of increasingly strict lockdown measures since November. Since last summer we have consistently emphasised that the economic recovery from the recession of 2020 is dependent on successfully controlling the virus.

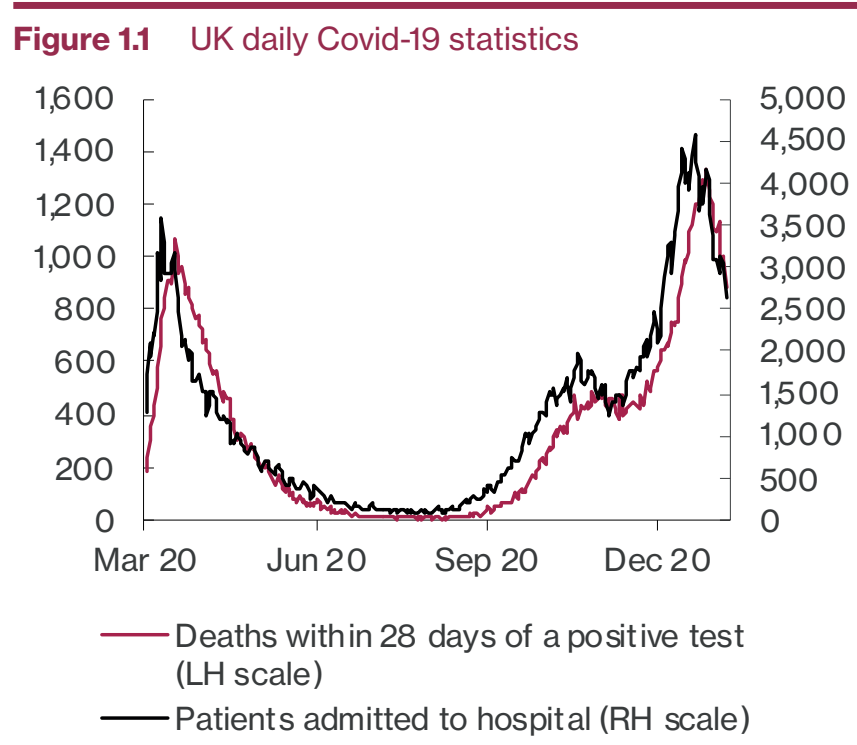

As well the occurrence of new lockdowns, the uncertainty around their deployment and of their duration have serious implications for economic activity as they make planning very difficult for households and businesses.

The initial partial re-opening of the economy during summer 2020 led to a rapid 'bounceback' in many sectors of the economy, but the persistence of the virus meant that the recovery was already petering out before restrictions were partially re-imposed in November in the form of a four-week national lockdown for England and similar measures in the devolved nations. Their lifting in December, combined with some stockpiling ahead of the Brexit deadline of 1 st January 2021, is likely to lead to a temporarily higher monthly growth rate, but with the UK economy still 8 per cent smaller than in December 2019. The tragic Covid-19 developments have led to the Coronavirus Job Retention Scheme (CJRS) being extended until April 2021 along with other fiscal support measures.

The Brexit deal removes a major risk while leaving in place some worries for the future.

The second main downside risk from November has now dissipated, with the signing of a Trade and Co-Operation Agreement with the European Union. Our previous main case forecast scenario incorporated the assumption of a Free Trade Agreement being signed, so this does not constitute a material change to the central scenario, but it does mean the removal of a major downside risk.

As described in our November 'Prospects for the UK Economy' the economic impact of Brexit is already evident in the UK economy, which is reflected in a lower assumed long-term growth path for the UK. Notably, the Agreement does not contain any provision for continued integration with the EU in financial services. The gaps opened by the Agreement require implementing mitigation policies and structural reforms over several years as well as negotiating trade agreements with key trading blocs in the rest of the world (Chadha, 2021).

1 We would like to thank Jagjit Chadha, Barry Naisbitt, Adrian Pabst and Garry Young for helpful comments and Patricia Sanchez Juanino for preparing the charts and the database underlying the forecast. The forecast was completed on 25 January 2021, more recent data are incorporated in the text. Unless otherwise specified, the source of all data reported in tables and figures is the NiGEM database and NIESR forecast baseline. All questions and comments related to the forecast and its underlying assumptions should be addressed to Cyrille Lenoël (c.lenoel@niesr.ac.uk). 
Figure 1.2 Google Community Mobility Reports

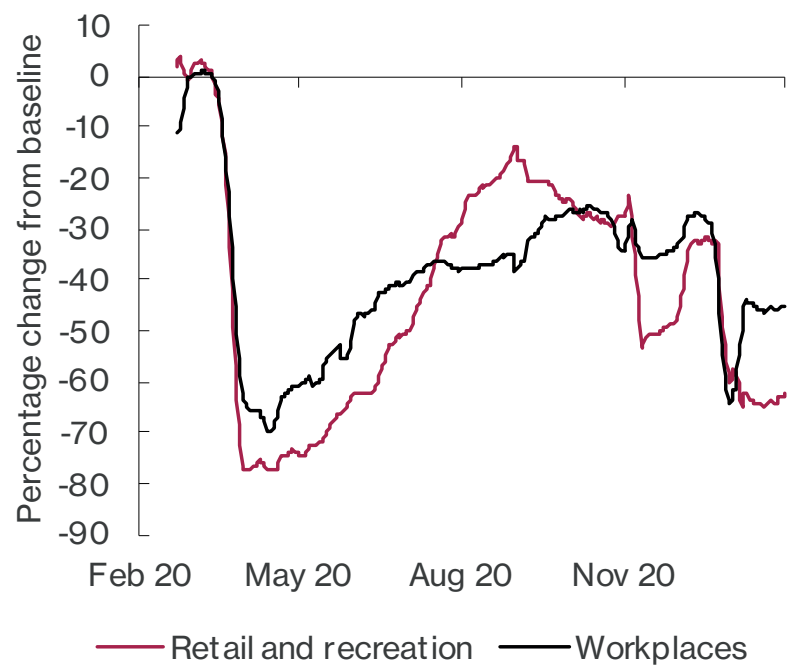

Note: Baseline is median value for the day of the week. Seven-day rolling average.

Source: Google, NIESR.
Figure 1.3 ONS spending and hiring indicators

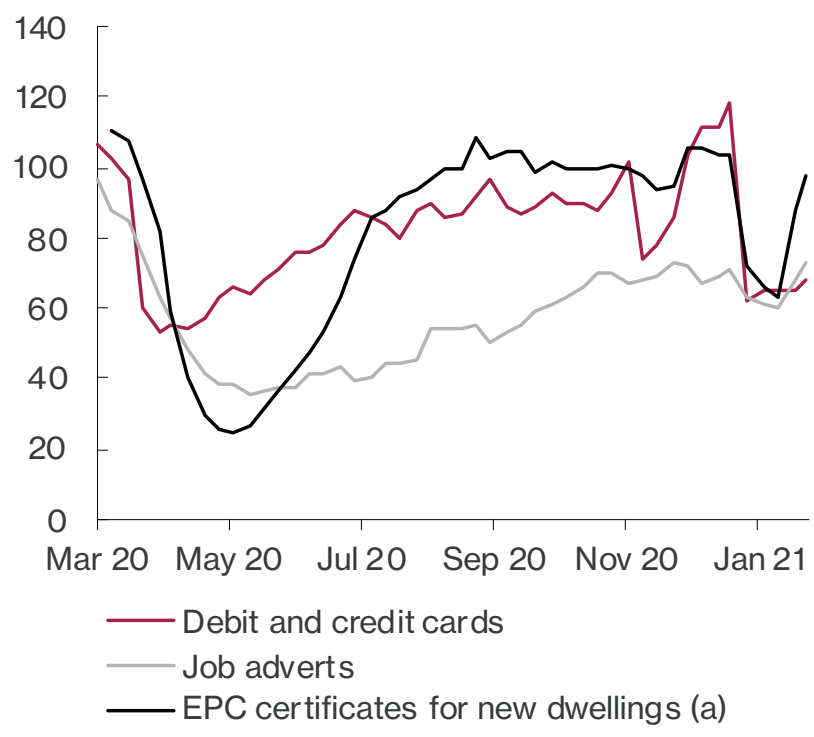

Note: a England and Wales. Debit and credit cards: 100 = February 2020, percentage change on a backward looking seven-day rolling average, non-seasonally adjusted, nominal prices. Job adverts: change from the same week in the previous year. EPC certificates: change from the same week in the previous year, four-week rolling average, adjusted for timing of December holiday.

Source: ONS, BoE, Adzuna, MHCLG.

slowly until the start of December, appear to have turned downwards again. Construction of new dwellings, which recovered quickly and strongly, may have begun 2021 at a subdued level compared with 2020 .

Private sector surveys suggest an economic contraction in early 2021.

IHSMarkit's purchasing manager indices suggest that December saw strong manufacturing growth (driven by stockpiling) but weakness in the much larger services sector. The flash PMI for services in January registered 40.6 in January: an 8-month low and significantly weaker than the final November reading of 49 .

Weak economic activity keep wages and price pressures subdued.

Data from the Labour Force Survey until November suggest that the November lockdown had limited impact on average weekly earnings. A fall in the number and proportion of lower-paid jobs led to earnings growth accelerating to 3.6 per cent in the three months to November after falling by 1.3 per cent in the second quarter and recovering by $1 \frac{1 / 2}{2}$ per cent the third quarter of 2020. Despite a late surge in average pay driven by composition effects, the National Institute Monthly Wage Tracker (January 2021) suggests that 2020 will end up being the worst year for total pay growth since 2014, with Average Weekly Earnings (AWE) growing at $1 \frac{1}{2}$ per cent on average. 
The National Institute Monthly CPI Tracker (January 2021) found that underlying inflation pressures are currently fairly stable, but regions that entered higher tiers of restrictions in December experienced marked decreases in consumer prices during the month.

\section{Economic activity}

A 10 per cent fall in 2020 and a slower recovery in 2021. Despite the November lockdown, we have revised up our forecast for GDP growth in 2020 from a fall of $10 \frac{1}{2}$ per cent to a fall of 9.9 per cent. This is because growth in the third quarter was slightly stronger than expected, and the effects of the restrictions in the fourth quarter are expected to be moderate.

Economic recovery in 2021 is highly dependent on the path of the pandemic.

Early indicators discussed in the previous section suggest that economic activity in January was lower than in November but higher than during Spring 2020. There are notable differences in the extent of restrictions compared with the first lockdown: far more children are attending schools and more employers have either invested in home working capabilities or are requiring staff to attend work. We forecast a contraction in the first quarter of 2021 (see figure 1.4), followed by a robust rebound in the following quarters as restrictions are lifted.

We assume lockdown restrictions persist for the most part of the first quarter and will be largely lifted from the second quarter on the back of a successful vaccine roll-out programme.

We assume in our main case forecast scenario that the current lockdown restrictions in England remain in place throughout January and February, with some easing

Figure 1.4 GDP: 2020 data and NIESR estimate

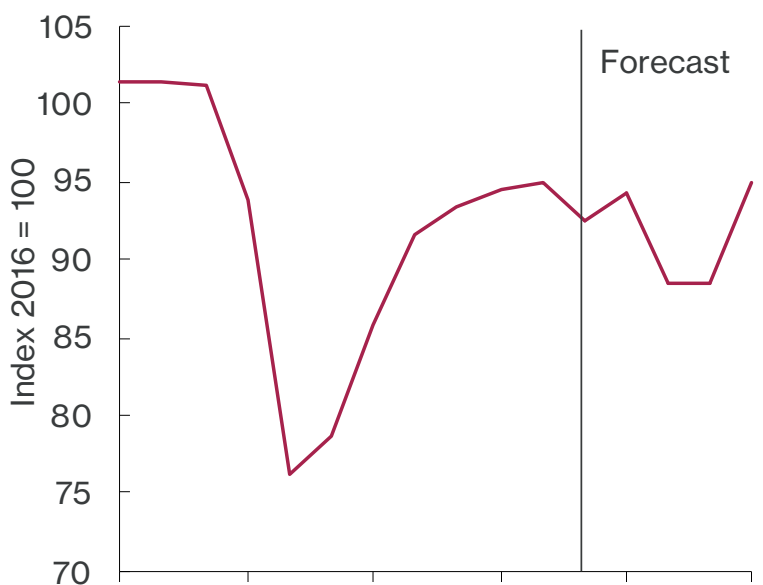

Dec 19 Mar 20 Jun 20 Sep 20 Dec 20 Mar 21

Source: ONS, National Institute Monthly GDP Tracker (January 2021). in March, before being largely lifted during the second quarter of 2021. In the main case forecast scenario our assumptions about restrictions are mainly reflected in the path of consumption, which is expected to recover in the second and third quarters (see figure 1.5).

Our forecast for 2021 is for year-on-year growth of 3.4 per cent, a revision down from our previous forecast of 5.9 per cent, reflecting the effects of the second wave of Covid-19 and associated lockdowns. Our forecasts are conditional on the assumption that Covid-19 vaccines are rolled out by the third quarter of 2021 to enough of the population that distancing restrictions may be safely lifted. Voluntary social distancing and remote working are likely to remain in place for a longer period until the pandemic is brought fully under control, and part of the shift to working from home may be permanent. Growth over the remainder of the forecast period reflects this gradual adjustment process (see figure 1.6) and an element of 'catch-up', as well as weak pre-pandemic trends in business investment and productivity growth, with GDP growth averaging 2.7 per cent over the forecast period. The UK economy is expected to return to pre-pandemic levels by the end of 2023, reflecting - compared with preCovid expectations - a lower path for consumption caused by higher unemployment, weaker business investment due to stressed balance sheets and uncertainty during the pandemic, and the adoption of an FTA with the European Union which imposes more barriers to trade than before. This implies an output loss of about 6 per cent by 2025 compared with pre-Covid expectations.

Risks come from Covid-19: a further resurgence or vaccine problems but also from policy errors.

Major risks to our new main case forecast scenario fall largely into two categories. Epidemiologically, if the vaccine roll-out is slower than expected, if further Covid-19 strains

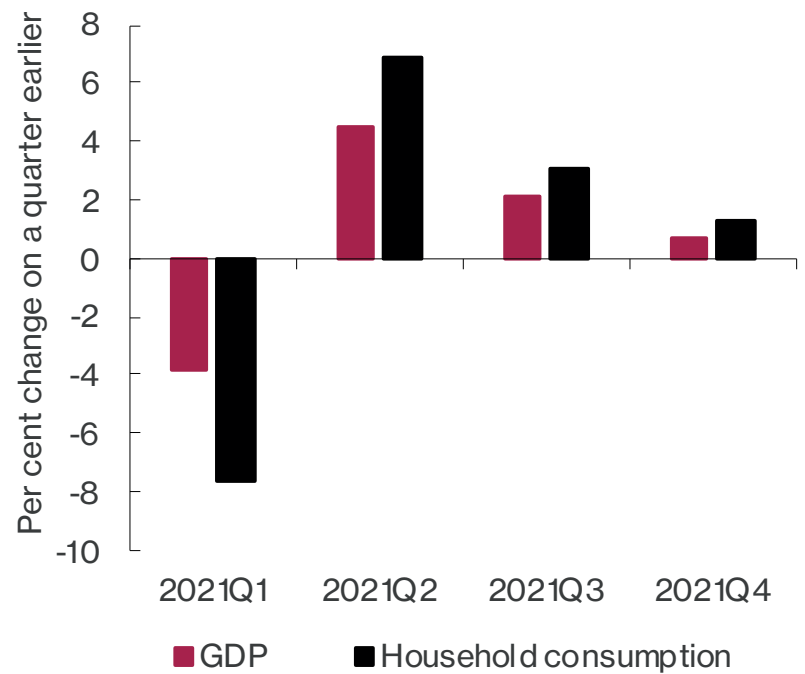

Source: NiGEM database and NIESR forecast. 
Figure 1.6 GDP fan chart

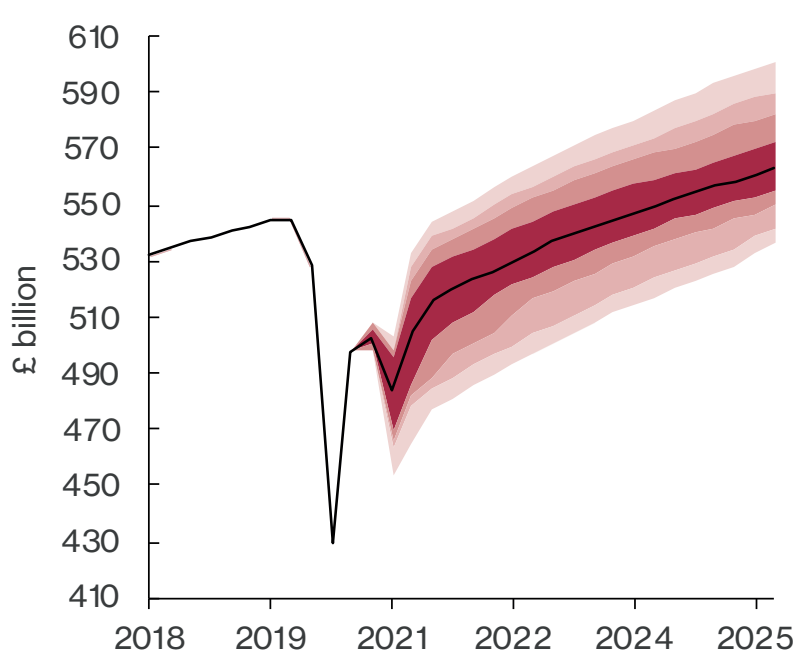

Notes: The fan chart is intended to represent the uncertainty around the main-case forecast scenario shown by the black line. There is a 10 per cent chance that GDP growth in any particular year will lie within any given shaded area in the chart. There is a 20 per cent chance that GDP growth will lie outside the shaded area of the fan

Source: NIESR forecast and judgement.

emerge which make the public health situation worse, or if for some other reason the virus is not controlled, the shortterm (and therefore long-term) impact on the economy may be far worse. A failure to distribute vaccines equally around the world is also a major downside risk on the UK economy not only through its implications on the path of the virus in the UK but also through its implications on UK's trade with the rest of the world. The long-term effects of the vaccines on the path of the virus are as yet unknown but our main case forecast is conditional on the disappearance of Covid-19 as a major cyclical concern in the medium-term future, albeit with permanent effects on the level of GDP. In the current main case, GDP is forecast to be around 6 per cent below the pre-Covid forecast by 2025 .

Fiscally, if Covid-19 support is withdrawn prematurely, or if consolidation is wrongly or prematurely applied in response to the increase in public debt, the economic recovery will be delayed and the long-term economic impact of the pandemic exacerbated.

If both turn out better than expected we could see a much faster recovery in demand...

Upside risks could be a faster than anticipated vaccination programme, a larger post-Covid consumer spending spree or a productivity boost arising from a Covid-enforced reallocation of capital towards automation and away from low productivity industries.

\section{...but there remain significant downside risks to the supply side of the economy}

The announcement of further restrictions has led to a downward revision of our GDP forecasts, driven by lower demand, but we do not foresee any additional scarring from the latest lockdown. By and large this reflects the belief that most firms which will not survive Covid-19 did not survive the first lockdown period, and that the second lockdown predominantly consists of temporary closures of businesses which have shown they can recover after restrictions are lifted. We would also expect some reallocation of capital to new businesses. Naturally if lockdown lasts for much longer than expected, or fiscal support is prematurely withdrawn, this may lead to further permanent closures, especially in social consumption sectors, but these remain downside risks to our forecast of supply. Risks to the supply side will be mitigated by policies to support domestic demand and the gradual evolution of internationally competitive industries.

There are additional risks due to difficulties in economic measurement during a pandemic.

Following scrutiny of official inflation calculations in the early stages of Covid-19, doubts have recently been cast on the official GDP and employment figures. Official GDP data, specifically public sector output, are constructed differently in the UK to other countries and, with nominal spending steady or even increased, the reduced level of normal activity (operations, doctor visits) led to an unprecedented 30 per cent rise in in the public sector deflator in Q2 of 2020. Initial estimates (Chadha and Dixon, 2020) in December suggested that measurement issues could lead to the level of GDP being reported at 3-6 per cent lower than its true level in the second and third quarters of 2020, though these should be considered no more than indicative.

\section{Households}

Unemployment only rose moderately thanks to the furlough scheme...

The unemployment rate rose to 5 per cent in the three months to November, which is equivalent to 1.7 million unemployed. This would undoubtedly have been higher if the government had not at the last moment committed to extending the CJRS until March 2021 (later further extended to April).

The Covid-19 pandemic has had important implications for the measurement of labour market statistics. In line with international standards, furloughed workers, who are temporarily away from work, are counted as employed as they remain contracted to an employer, keeping the 
Figure 1.7 Number furloughed

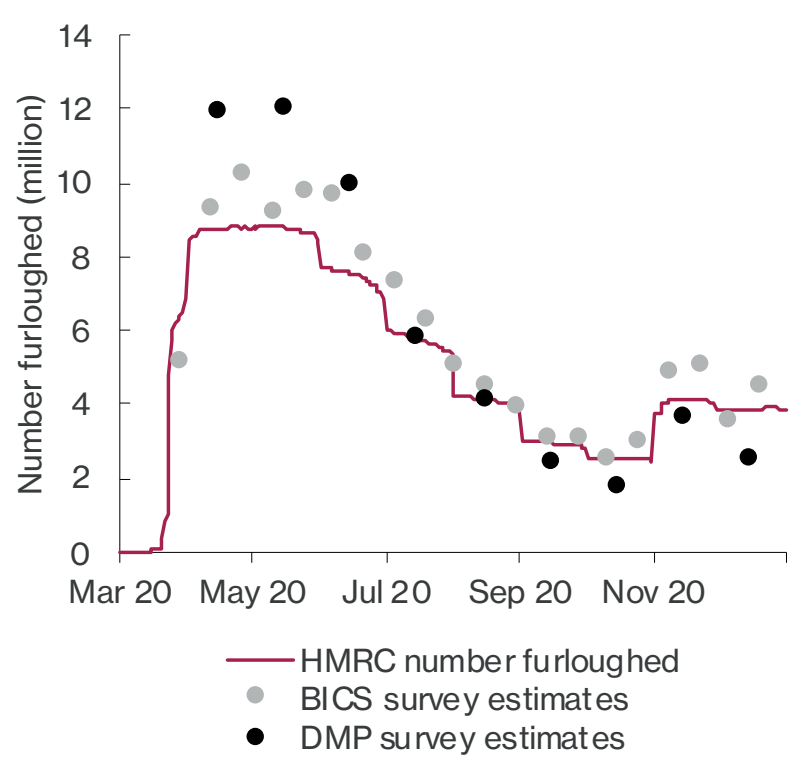

Source: HMRC, ONS Business Impact of Coronavirus Survey, Bank of England Decision Maker Panel survey.

unemployment rate down. There is also a significant number of people temporarily away from work because of the pandemic but not being paid at all who report themselves as employed in the Labour Force Survey. ${ }^{2}$ This is another factor that potentially keeps unemployment rate down.

The Labour Force Survey measurement of employees has also come under scrutiny. Research at NIESR's Economic Statistics Centre of Excellence (O'Connor and Portes, 2021) suggests that the absence of data on migration during the pandemic has led to the LFS reporting a 200,000 increase in employees rather than a fall of up to 750,000 . The ONS responded by explaining that the LFS is a measure of rates and not levels and that population estimates will need to be revised once the impact of the pandemic on international migrations is better understood. As with the GDP figures, the aggregate number of employees in our forecast should be treated with caution, based, as it is, on the official data as it currently stands.

In our November forecast we suggested that surveys were compatible with around 2.5 million workers being furloughed in October: official data have since confirmed this. The number of furloughed workers increased in November to about 4 million because of the second lockdown. That number is likely to increase in January 2021 , but to stay below the 9 million peak during the first lockdown (figure 1.7).
Figure 1.8 Unemployment rate and forecast

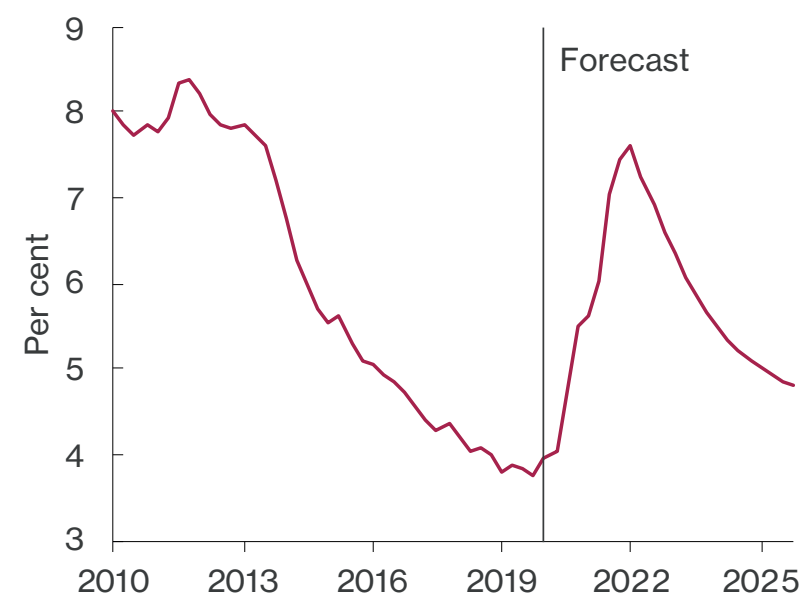

Note: Unemployment rate is the number of unemployed people (aged 16+) divided by the economically active population (aged $16+)$.

Source: NiGEM database and NIESR forecast.

The number of redundancies in the three months to November 2020 increased by 280,000 on the year to a record high of 395,000 . The number of vacancies in the three months to December increased to 578,000 from a trough of 343,000 in the three months to June. It remains well below the pre-pandemic levels of above 800,000 .

... but will rise to $7 \frac{1}{2}$ per cent in early 2022 without further support.

In our main case forecast scenario the unemployment rate peaks at $7 \frac{1}{2}$ per cent in the first quarter of 2022 , and then falls gradually to reach 4.9 per cent in 2025 (see figure 1.8). The delayed peak is partly a result of the extending the CJRS, which at the time of our last forecast was expected to end in October 2020, and partly due to uncertainty, damage done to corporate balance sheets and lower investment. Lessons from previous recessions also suggest that unemployment tends to peak several quarters or years after the end of a recession. For example, unemployment peaked at 8.2 per cent in the second quarter of 2012, about 3 years after the end of the 2008-9 recession and there were similar length lags in the 19801 and 1990-1 recessions. Reallocation of labour as the economy adjusts to sectoral shifts due to both Covid-19 and Brexit also suggest a delayed recovery in the labour market. Unemployment stays above the pre-pandemic rate of 4 per cent even at the end of our forecast horizon.

2 See ONS blog by Jonathan Athow July 16, 2020. https://blog.ons.gov.uk/2020/07/16/a-covid-19-conundrum-why-are-nearly-half-a-millionemployees-not-being-paid/ 
Figure 1.9 Average weekly earnings by sector in 2020

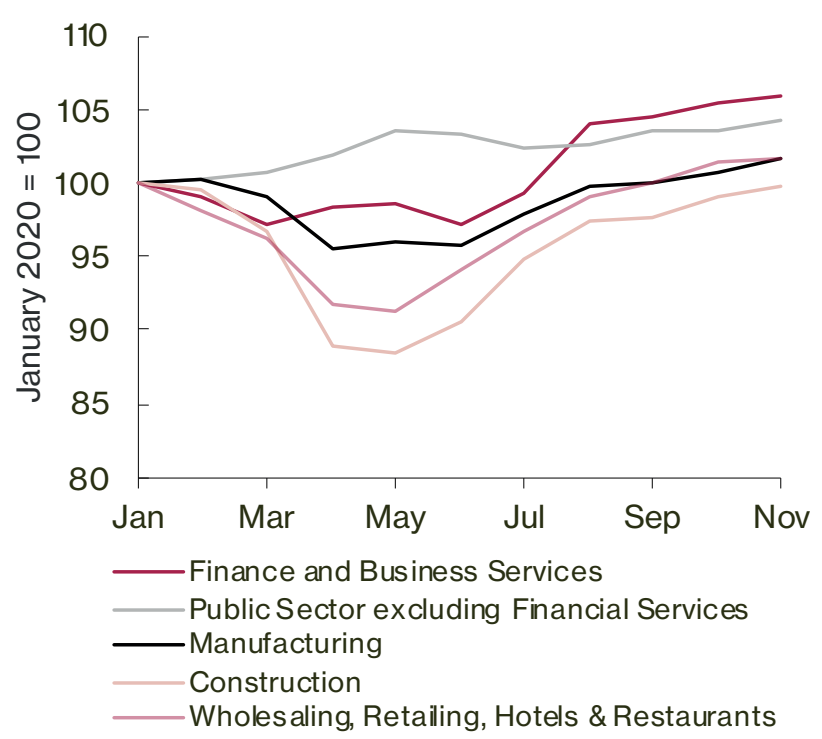

Source: ONS. Seasonally adjusted.

The high degree of uncertainty surrounding the recovery calls for a state-contingent job support scheme.

The labour market policy has so far consisted in rolling over the CJRS and Self-Employed Income Support Scheme (SEISS) whenever a new lockdown was announced. While this policy was successful in limiting the rise in unemployment that would have occurred without these schemes, it did not allow businesses to plan ahead because the extensions were announced too close to the previously announced end of schemes. The furlough scheme that was originally planned to end on 31 October 2020 was initially extended by a month on the very same day following the announcement of the November lockdown by the Prime Minister. A few days later, on 5 November 2020, the Chancellor announced an extension until the end of the March 2021. A further extension to the scheme until April 2021 came on 17 December 2020 as lockdown restrictions were tightened once again.

To prevent a rise in unemployment of the magnitude of our forecast, the Chancellor should announce as soon as possible policies to follow the CJRS when it is due to expire in April. By this time, a significant part of the labour force will probably still be furloughed. Our recommendation is to continue to support the labour market beyond April with local and sectoral schemes targeted towards businesses that are most affected by Covid-19 restrictions. The new schemes ought to consider the degree of restrictions imposed in a region, as well as how the restrictions affect each sector. Similar schemes are also needed for the self-employed. The March Budget should clearly lay out government policies which both protect jobs until the pandemic is brought under control
Figure 1.10 Whole economy trends in pay review outcomes, 2020

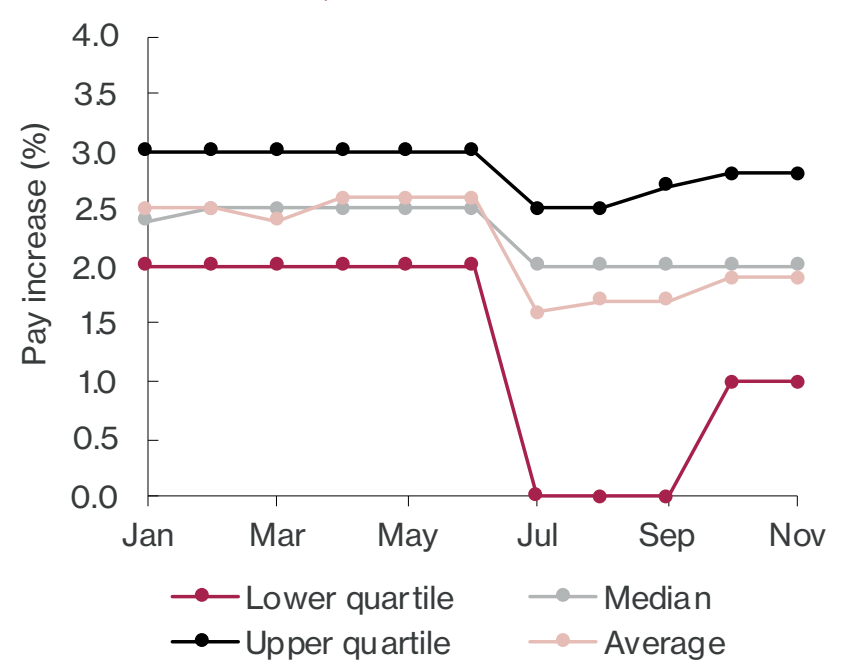

Source: Incomes Data Research.

and encourage the transition to new ones as discussed in Macqueen (2020b).

There have been dramatic wage falls concentrated in the worst affected parts of the economy.

Average earnings are expected to have held up relatively well in 2020 thanks to direct and indirect government transfers, growing by 1.9 per cent compared to 2019 , though this disguises significantly different outcomes across the economy (see figure 1.9 for the sectoral decomposition of average weekly earnings excluding Northern Ireland). Clearly the degree of furloughing correlates highly with falls in earnings, with not all employers 'topping up' the 80 per cent of wages subsidised by government (Küçük, Lenoël, Macqueen, 2020 and Macqueen, 2020c).

Incomes Data Research analysis suggests that, while the number of pay freezes increased dramatically in the middle of 2020 , the median award fell only slightly, suggesting that many companies and sectors remained largely unaffected (figure 1.10) while others clearly were not. Redundancies and low levels of recruitment have disproportionately affected low-paid jobs, which has the effect of raising the average.

We forecast average earnings to fall by 1.1 per cent in 2021 because of pay freezes and wage moderation, then grow by an average of 3.2 per cent per year over the remainder of the forecast period (table A5).

As a result of the above we forecast real personal disposable income to grow by 0.7 per cent in 2021 , as government transfers and rising average hours slightly outweigh the effect of falling employment and hourly wages (table A5). 
The housing market remains strong partly thanks to government support.

We have revised up our estimate for house price growth in 2020 from 0.5 per cent to 3.1 per cent due to strong activity in the housing market in the second half of the year driven by pent-up demand, the stamp duty holiday and people reassessing their housing needs in light of increased working from home. The Halifax house price index was 6 per cent higher in December 2020 than a year ago. Mortgage approvals have risen in November 2020 to 105,000 , the highest number since August 2007 while HMRC monthly property transactions stood at 115,190: 19 per cent higher than a year earlier.

This momentum is likely to continue despite the lockdown as estate agents can carry on working and viewings can still be organized either virtually or on site with precautions. We forecast house prices to increase by close to 4 per cent in 2021 and housing investment to increase by 10 per cent after decreasing by 10 per cent in 2020 (table A5). However, the end of the stamp duty holiday ${ }^{3}$ and of Help to Buy (in its current form) in March 2021, combined with an increase in unemployment, is likely to put downward pressure on the housing market in the remaining years of the forecast period.

\section{A tale of two pandemics: some barely affected, others plunged into poverty.}

The overall impact of the Covid-19 pandemic on household finances, as on employment and other economic variables, has been highly uneven. Households who reported having increased their savings had incomes 45 per cent higher than those who had decreased their savings (Bank of England, 2020). Low-income households have seen their saving rates decline sharply as their earnings fell more than their expenditure (Hacioglu et al, 2020). In contrast, middle- and high-income households have seen their saving rates increase due to containment measures that restricted spending on contact-intensive services and nonessential goods.

\section{Household spending has been reallocated from hospitality to retail.}

As with household income, household spending changes varied in 2020. Retail was one of the fastest sectors to recover from a significant fall in output during the first Covid-19 lockdown and activity was just 4 per cent below its February level in November, compared with 36 per cent in April 2020. Retail sales rose by only 0.3 per cent month-on-month in December, ${ }^{4}$ with the British Retail Consortium survey reporting strong divergence: record spending on food and groceries but a "dismal" December on the high street for non-essential high street shops. ${ }^{5}$ Some of the strength of retail over 2020 results from substitution away from unavailable social consumption in bars, restaurants, and the like.

While the hospitality sector is undoubtedly badly affected by the re-emergence of the virus, there is evidence that some businesses have successfully switched to providing takeaways. Barclaycard data suggests that restaurant, bar and pub spending was down by around two thirds in December year-on-year. ${ }^{6}$

A potential consumer recovery may be held back by the weak growth in household incomes.

We forecast household consumption to rise by 2.6 per cent in 2021 after a fall of 11.6 per cent in 2020 . Our downward revision to household consumption since November is largely the result of the current wave of Covid-19 that restricts consumption and reduces income during the third lockdown that is expected to last for a large part of the first quarter (figure 1.5). The household savings ratio is forecast to fall only moderately from 17 per cent in 2020 to 15 per cent in 2021 . This is in line with recent evidence suggesting that serious economic downturns can 'scar' consumers in the long run by increasing their tendency to save (Malmendier and Shen, 2020; Kozlowski et al, 2020). One upside risk to household consumption (with consequences for demand, wages and inflation) comes from the potential for a lifting of restrictions sooner thanks to a successful vaccines rollout. Accompanying our August forecast we simulated (see Macqueen, 2020a) consumer optimism returning sooner than expected while the Bank of England maintained loose monetary policy due to lingering high unemployment and continued low inflation.

\section{Firms}

The pandemic has led to some businesses seeking significant financial support though by no means all. As it has with households, the Covid-19 pandemic has affected the business sector unevenly: some sectors which were badly affected at first have recovered strongly, others less so (see section 2 ).

Supply and demand for credit has not been uniformly distributed across the corporate sector. Lending to small and medium sized enterprises (SMEs), including government support, totalled $£ 54$ billion in the first three quarters of 2020, more than double its 2019 total for the same period. ${ }^{7}$ The Federation Small Businesses' quarterly Small Business Index in January suggested that a record 250,000 of firms are set to close in 2021 in the absence of further government support.

3 According to OBR November 2020 forecasts, the expected cost of the stamp duty holiday between 8 July 2020 to 31 March 2021 is $£ 3.3$ billion.

4 https://www.ons.gov.uk/businessindustryandtrade/retailindustry/bulletins/retailsales/december2020

5 https://brc.org.uk/retail-insight/content/retail-sales/retail-sales-monitor/reports/202012_uk_rsm/

6 https://home.barclaycard/press-releases/2021/01/Consumer-spending-declined-2-3-per-cent-in-December/

7 https://www.ukfinance.org.uk/system/files/Business-Finance-Review-2020-Q3-Final.pdf 


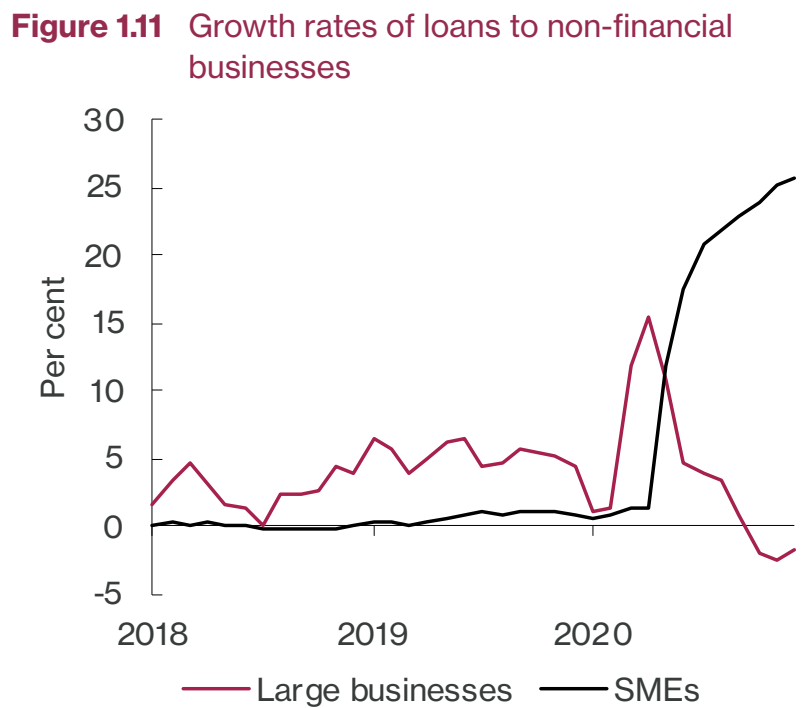

Source: Bank of England.

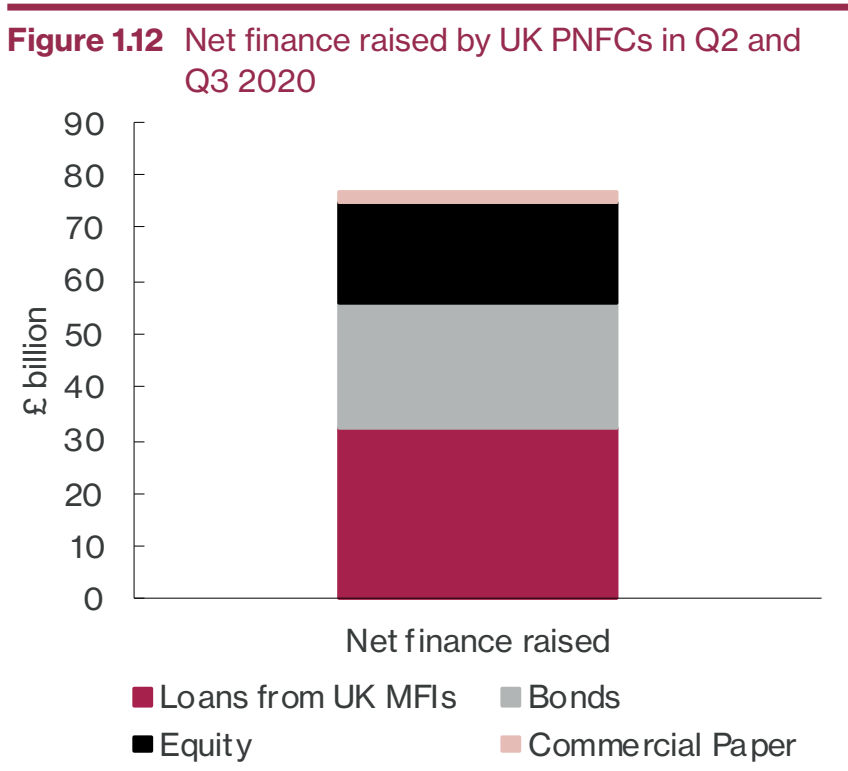

Source: ONS. Seasonally adjusted.
At the same time evidence from NIESR's Business Conditions Forum is that many large corporates drew on revolving capital facilities, took short term financing (public and private sector) and repaid from cash flow. In November, during the second lockdown in England, lending to non-financial businesses was 25 per cent higher than a year ago for SMEs but 3 per cent lower for large firms (see figure 1.11). The lower credit for large corporates may also reflect their focus on cutting costs and investments during a period of weak demand.

Higher borrowing during the pandemic will weigh on some corporate balance sheets for years to come.

As the recovery takes hold during 2021 and 2022 the focus of corporate borrowing is likely to switch from whether firms are able to access enough credit to survive to whether they have taken on more than they can service. By some distance the largest government loan programme has been the Bounce Back Loan Scheme, accounting for $£ 44$ billion of the $£ 68$ billion of lending made up to 13 December and on which repayments will have been disproportionately made by those with healthier cashflows. ${ }^{8}$

The Bank of England Financial Stability Report in December estimated that companies would face cashflow deficits of up to $£ 178$ billion in the $2020-21$ fiscal year, well-above typical values for cash-flow deficit for businesses which is around $£ 100$ billion. According to these estimates, if used, cash buffers could cover almost half of the cash-flow deficits. Along with the cash buffers, the net increase in finance that amounted to $£ 77$ billion between March and October 2020, have helped businesses finance the unusually high levels of cash flows in this period (see figure 1.12). Stricter lockdowns since then might imply higher financing needs given the effects on cash-flows through reduced economic activity.

Equities have been supported by accommodative monetary policy, but compared with other major large corporate indices, the UK's relative economic stagnation since summer 2020 can be seen from figure 1.13.

The Deloitte quarterly survey of Chief Financial Officers in January recorded that a net 58 per cent were more optimistic about their companies' prospects compared with three months earlier but, while those expecting increases in spending improved, the net number remained negative. The CBI's Industrial Trends survey from January suggested a significant degree of stockpiling in the quarter to January, with significantly weaker outlook over the first quarter of 2021.

An uncertain demand recovery may be accompanied by uneven growth in supply capacity.

Servicing acquired debt will weigh on balance sheets for the next few years, especially in the sectors most affected by Covid-19. Although corporate bond spreads have been stable and close to their historical levels, increased debt service requirements might hold back investment and productivity by increasing fixed costs.

8 https://www.gov.uk/government/collections/hm-treasury-coronavirus-covid-19-business-loan-scheme-statistics 
Figure 1.13 Stock indices: large companies

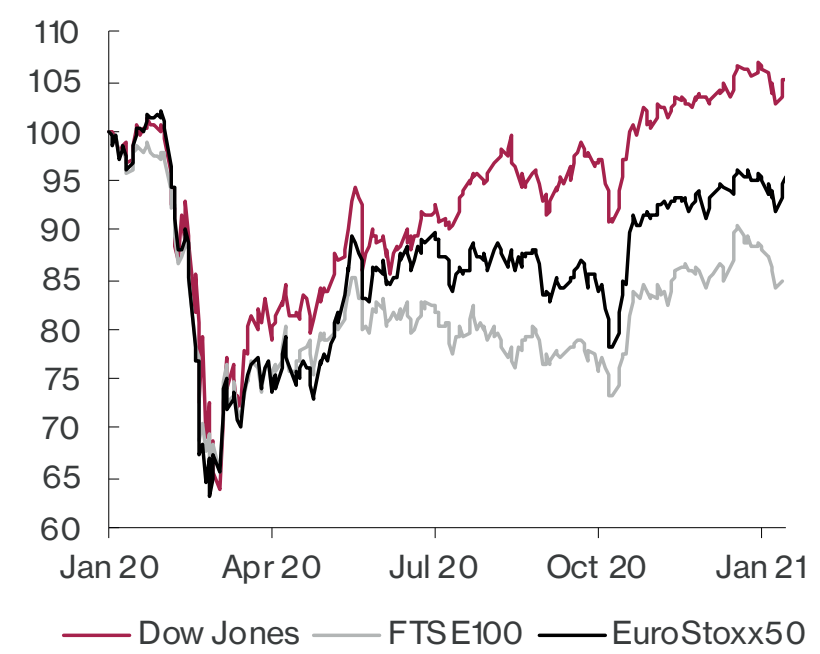

Source: Yahoo Finance.
Figure 1.14 UK labour productivity (GDP per hour worked)

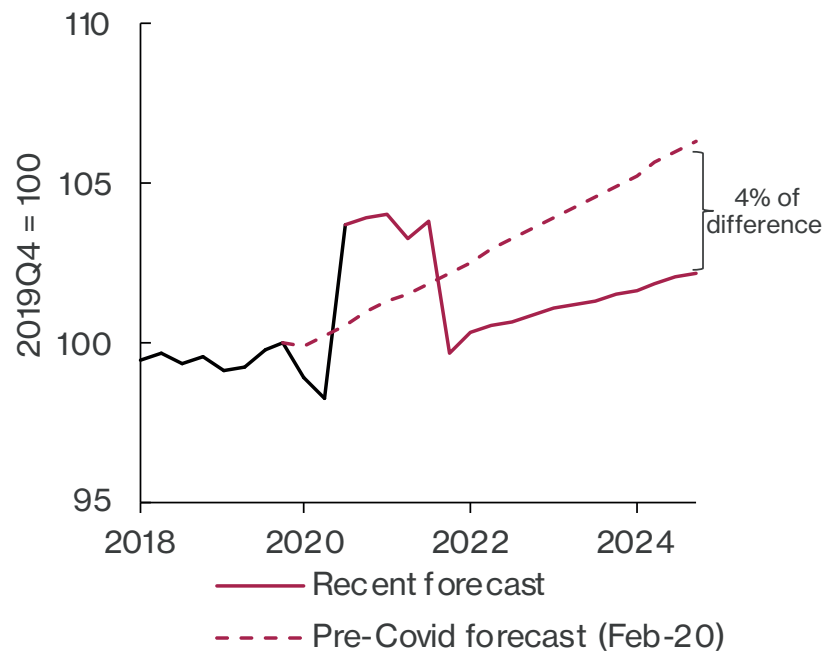

Source: NIGEM database and NIESR forecast.

\begin{abstract}
Labour productivity has been temporarily higher during the pandemic.

Covid-19 led to an unusual increase in output per hour worked because hours worked fell more than output. The winter lockdown and the possibility of further restrictions during the year are likely to keep productivity temporarily higher in 2021. We forecast output per hour to increase by 1.8 and 1.6 per cent respectively in 2020 and 2021 before dropping by 2.3 per cent in 2022 . Productivity would then go back to pre-Covid growth rates of about $1 / 2$ per cent per year.
\end{abstract}

Figure 1.14 shows that this path for productivity implies a 4 per cent scarring compared to our pre-Covid forecast. Approximately half of the scarring can be attributed to the change in assumption from a soft Brexit to an FTA and half from the long-term impact of Covid-19. A downside risk to our productivity forecast is related to Brexit and weak capital accumulation and an upside risk is related to potential productivity gains from increased investments in digitalization during the pandemic, which could support a long-run improvement (Van Ark et al., 2020; Bloom et al., 2020).

\section{Trade}

The Brexit deal is better than a no-deal outcome but will still imply significant losses through trade and productivity compared to staying in the EU Single Market.

After a long period of negotiations, the UK and the EU have signed a Trade and Co-Operation Agreement with the European Union that came into force on the 1st January 2021. Our November forecast (Küçük, Lenoël,
Macqueen, 2020) incorporated the assumption of a Free Trade Agreement (FTA) with the EU that would provide a high level of access in the goods sector but a poor level of access in services, which is broadly in line with the signed trade deal. Hantzsche and Young (2019) estimated that in the long run the UK economy would be $3 \frac{1}{2}$ per cent smaller under an FTA deal compared to continued EU membership, mainly due to reduction in trade and migration as well as weaker productivity growth.

As in our previous main case scenario, the economic impact of Brexit is reflected in a lower assumed long-term growth path for the UK. Hence, according to the signed trade deal, there should be no tariffs levied on bilateral trade of goods between the UK and the EU as before provided that the rules of origin can be met. While this will reduce the losses from leaving the EU compared to a no-deal outcome, other costs of accessing the EU market come from an increase in non-tariff barriers and rules of origin which will make bilateral trade more difficult in comparison to the UK being a member of the EU (Ayele et al, 2021).

Despite the significance of services trade for the UK, services provisions in the trade agreement are thin, or even non-existent as in the case of financial services, implying a major change compared to the arrangements under the EU Single Market. The EU Single Market facilitates the international integration of EU services markets by the country-of-origin principle. However, under the new agreement, UK businesses will be subject to rules prevailing in the receiving country rather than the rules prevailing in the UK with potentially severe implications for air transportation, financial services and many professional and business services (Borchert and 
Figure 1.15 Sectoral balances (saving minus investment)

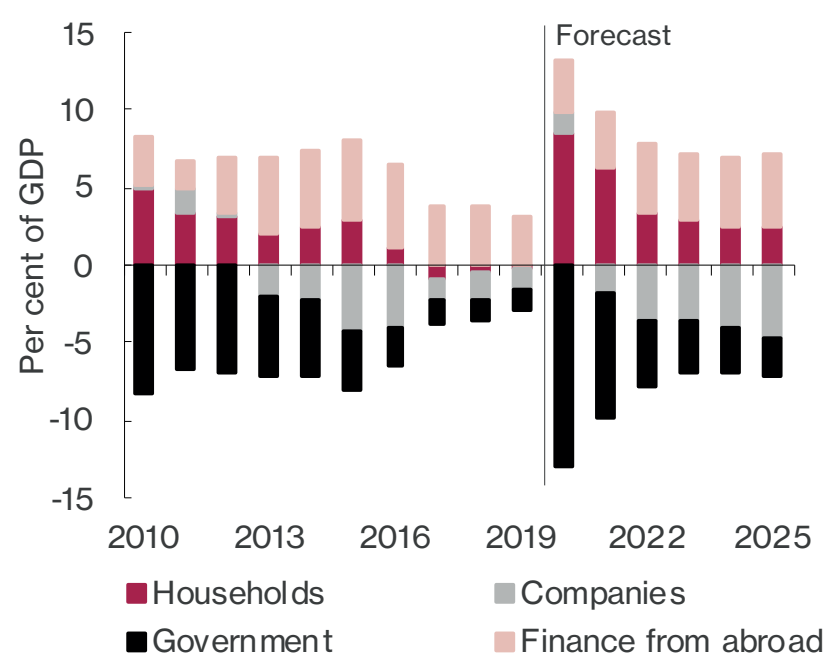

Source: NiGEM database and NIESR forecast.

Morita-Jaeger, 2021). The lack of a trade agreement on services implies that the economic recovery cannot easily fall back on sectors like financial services which have been less exposed to the effects of Covid-19.

In our main-case forecast scenario, export and import volumes fell by around 15 per cent and 20 per cent respectively in 2020 reflecting the dramatic fall in world trade and the large contraction in economic activity due to Covid-19. Exports are expected to recover gradually by around 3 per cent and 9 percent in 2021 and 2022, respectively, due to the exit from the EU Single Market. Imports are expected to recover much faster, driven by recovering consumer spending, leading to a rising current account deficit from 2021. There are significant downside risks to our forecasts of exports and imports, depending on the extent of disruptions from Brexit and the pace of recovery from the pandemic across the world.

As the economy recovers from the pandemic on the back of consumption, domestic savings of households will gradually fall. Net financial position of the corporate sector will turn negative as business investment picks up. These will contribute to a decline in government net borrowing and imply a slight increase in current account deficit, i.e. net finance from abroad to fill in the saving and investment gap during recovery (see figure 1.15).

\section{Fiscal policy}

Fiscal support is money well spent.

The wide range of emergency measures introduced by the government since the beginning of the pandemic to support businesses and households have prevented a much sharper contraction than the 9.9 per cent decline in GDP that we predict for 2020 (Holland and Lenoël, 2020). Since our
November forecast the principal fiscal development has been the extension of existing forms of Covid-19 support as a result of the further public health restrictions which have been introduced to halt the resurgence of the virus. NIESR called for the CJRS extension from July 2020, on the basis that it would protect the economy and pay for itself through higher taxes and lower welfare spending; its late announcement will, however, have reduced its benefits.

The government has undertaken large amounts of borrowing but most of it is temporary.

As a consequence of the economic crisis caused by the pandemic and the associated government measures to contain the virus, the government deficit has risen substantially. The increase in the budget deficit resulted partly from greater spending and transfers and partly from lower tax receipts during the downturn. Government revenues declined because of reduced economic activity and tax breaks and holidays, while expenditure increased to provide much needed support to businesses and households. Examples of new expenditure are the CJRS and SEISS that we estimate will cost the Treasury up to $£ 100$ billion in the $2020-21$ fiscal year.

In its November Economic and Fiscal Outlook the Office for Budget Responsibility estimated that government borrowing would increase to $£ 394$ billion in the fiscal year 2020-21 (19 per cent of GDP) and $£ 164$ billion in 2021-22 (7.4 per cent of GDP), with government debt peaking at 109 per cent of GDP in 2023-24. Since then, the December data show that borrowing has turned out $£ 44$ billion lower than the OBR forecast in the first 9 months of the fiscal year because of higher tax receipts and lower public spending. But on the other hand, the winter lockdown is expected to push up the deficit in the last quarter of the current fiscal year because of additional spending related to the extension of the job support scheme and lower revenues in the sectors most hit by the lockdown.

The deficit stays persistently high during the forecast period.

Assuming no change in policy, borrowing reaches $£ 364$ billion (17.6 per cent of GDP) in 2020 and $£ 135$ billion (6.1 per cent of GDP) in 2021. A downside risk to our forecast results from the losses that the Treasury could incur in the case of write-offs from pandemic loans, which we have not explicitly accounted for because they are very uncertain. The OBR estimates the write-offs could reach $271 / 2$ billion in $2020-21$, or 1.3 per cent of GDP. The deficit then gradually falls to 3.4 per cent of GDP in 2025. This is a full percentage point higher than the average of the deficit in the years from 2016-2019, and highlights the persistent impact of COVID-19 on the budget deficit. The higher deficit comes a combination of lower GDP which reduces tax revenues and higher expenditure. Küçük and Whyte (2021) show that a good rule of thumb is that a 1 percentage point decrease in GDP growth results in a 0.8 percentage point increase in expenditure growth. 
Receipts and spending are both forecast to be larger as a share of GDP but spending is expected to have risen slightly more, partly as a result of the increased investment programme announced before the pandemic (see Table A8) and higher unemployment. Our main case forecast scenario includes no additional discretionary fiscal consolidation beyond the $£ 13$ bn announced at the Autumn Statement in the form of a public sector pay freeze, cuts to local authority funding and overseas aid.

Interest rates stay low despite the higher debt, and debt sustainability does not appear to be under threat.

Public sector net debt increased to 99.4 per cent of GDP in the 9 months to December 2020 - the highest debt to GDP ratio since the financial year ending in 1962, and we estimate that it will reach 108 per cent of GDP in 2020-21 and 110 per cent in 2021-22 (see Figure 1.16). Debt should only decline moderately in the following years, reaching 106 per cent of GDP in 2025. The higher level of debt has not prompted any worry from financial markets about the ability of the UK to service its debt. All three major credit agencies S\&P, Fitch and Moody's rate UK-issued bonds just 2 or 3 levels below the maximum rating. 10-year gilt yield reached a record low of 0.1 per cent in August 2020 and stayed between 0.2 and 0.4 per cent since then (see figure 1.17). We forecast gilt yields to increase only very moderately in the next few years and interest payments to actually fall as a share of GDP, from 2.2 per cent in 2020-21 to 1.7 per cent in 2025-26.
It may at first appear advantageous for the UK to 'lock-in' the low interest rates and increase the average maturity of debt by issuing more longer maturity bonds and purchasing shorter maturity bonds. Such new longmaturity bonds may be required for example to finance new infrastructure projects as part of the objective to increase public sector net investment to 3 per cent of GDP. But the Debt Management Office, which is the agency that manages UK debt, must balance this opportunity with the necessity to provide liquidity for the market at all sorts of maturities, including short maturities.

One reason for low gilt yields is clearly the Bank of England's continued participation in the bond market: something we anticipate continuing for some time (see figure 1.17). In theory the expansion of the Bank of England's gilt holdings presents a fiscal risk: the fiscal benefit of quantitative easing is the difference between gilt rates and interest paid on Bank reserves, so an increase in the latter may lead to a fall in the Bank's profits which are returned to HM Treasury. However, the central case scenario for interest rate rises is included in fiscal forecasts and any larger or earlier rises in interest rates are likely to have been occasioned and accompanied by a larger or earlier recovery in the economic and, therefore, in the fiscal forecasts: any fiscal risk arises from the confluence of slow growth and higher inflation.
Figure 1.16 Public sector net debt

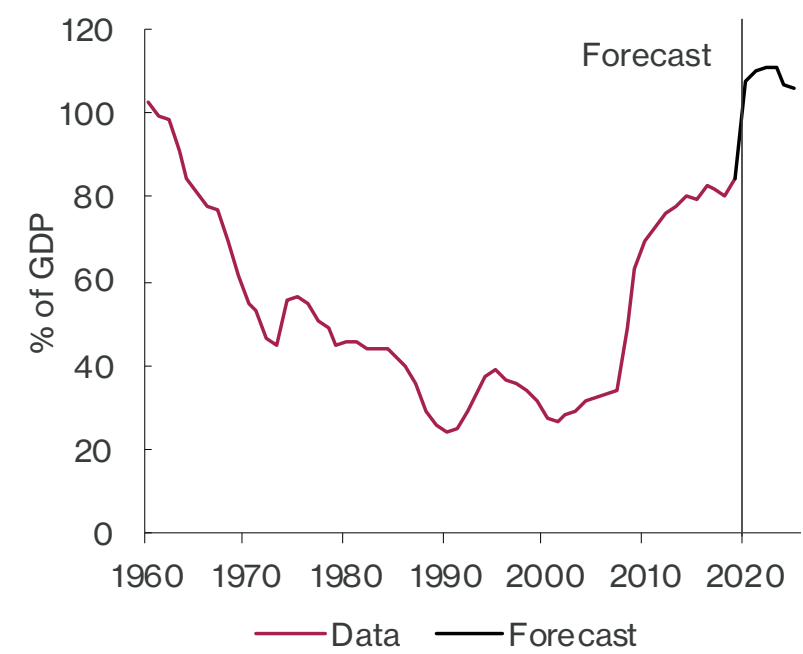

Source: ONS, NIESR forecast.
Figure 1.17 Public sector net debt and 10-year gilt

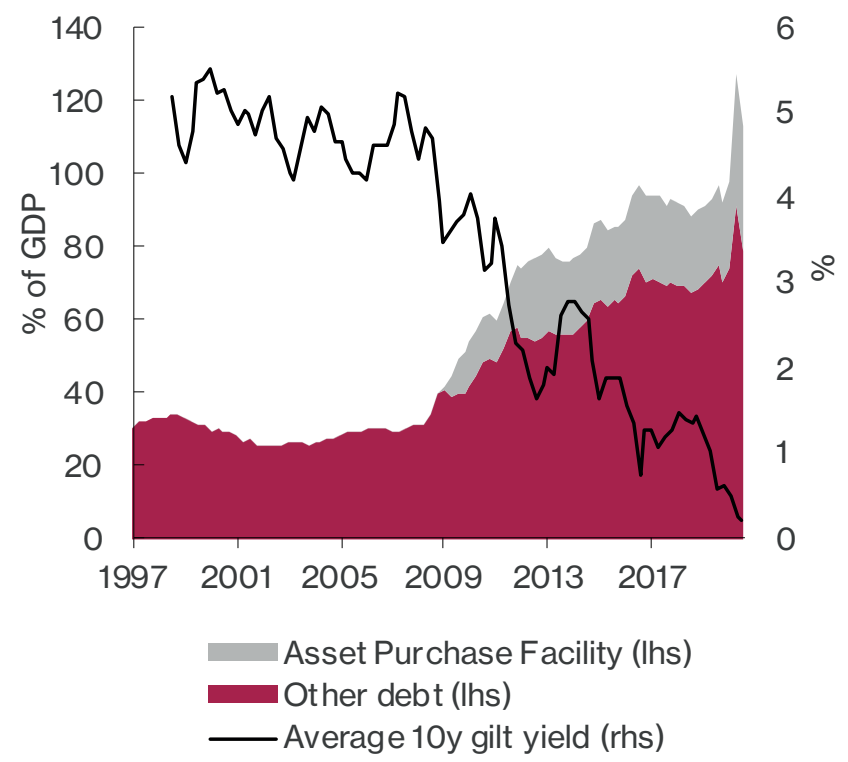

Source: Debt Management Office, NIESR. 


\title{
Box A A post-Covid fiscal consolidation
}

\author{
By Cyrille Lenoël and Kemar Whyte
}

Given the immense pressure on the Chancellor of the Exchequer to outline a plan to steer the economy out of the doldrums and restore public finances, using NiGEM, NIESR's global macroeconometric model, we present different scenarios of fiscal consolidation to reduce the deficit by 2 percentage points in 3 years. In doing so, we assume that the consolidation does not start until the pandemic is brought under control and the economy is on a steady recovery path. The size of the consolidation of 2 per cent of GDP is taken from the estimated long-term impact of the pandemic on the deficit estimated in the OBR November 2020 forecast.

Simulation results depend crucially on the parameters that govern the size of the fiscal multipliers, defined as the ratio of the change in national income arising from an exogenous change in government spending or revenue plans. Fiscal multipliers in NiGEM are based on historical estimates, i.e. estimates obtained during 'normal times', and therefore would not be applicable during crisis periods, especially when significant parts of the economy are shut down to control the spread of the virus. Therefore, we analyse alternative consolidation strategies when the economy has recovered most of its losses due to Covid-19.

Figure A1 shows the implied multipliers for a set of tax and spending shocks based on historical estimates. A smaller multiplier is preferable in the case of a consolidation because it gives a smaller reduction in GDP for a given increase in government revenues or reduction in government spending. We find that the smallest tax multiplier is for income $\operatorname{tax}(0.2$ after 3 years) and the largest multiplier is for corporate tax (0.6). The increase in income tax reduces real personal disposable income. Households reduce consumption, but also decrease their savings to preserve some of the consumption. The increase in VAT leads to higher consumer prices, which also reduce real personal disposable income. But it also hits the corporate sector because workers ask for higher wages to keep up with inflation and this increases producer costs and reduces their profits. Lower private sector investment is moderated by the fact that we assume that the Bank of England does not immediately respond to the inflationary effect of the VAT hike, which means that real rates decrease. The highest multiplier is for corporate tax because of its negative effect on the supply side. The increase in corporate tax leads to higher user cost of capital, which results in a permanent decrease in investment and therefore of potential output. Corporate profits are squeezed and the demand for labour diminishes. Household income is reduced because of higher unemployment.

The average spending multiplier is about the same as the average tax multiplier at slightly below 0.5 . The literature finds that multipliers tend to be time and state-dependent (see for e.g. Lenoël, 2020; Sims and Wolff, 2017; and Canzoneri et. al, 2016). Because there is currently a large negative output gap and the Bank Rate is at the effective lower bound, we have reasons to believe that the multipliers may be larger than usual, and starting a consolidation too soon or too aggressively may tip the economy back into a recession.

We run two simulations, one of a tax increase and one of a spending cut. Both simulations are calibrated to a 2 per cent reduction in the deficit in the three years following the start of the consolidation. The tax increase is equally split among increases in income tax, corporate tax and VAT, so that each tax increase should increase revenues by $2 / 3$ of GDP in three years. We calculate that to achieve this, effective corporate tax rate needs to increase gradually from 10.7 per cent to 13.9 per cent, VAT from 20 per cent to 21 per cent and the effective income tax rate from 22.3 per cent to 23.1 per cent. The tax increases are assumed to be spread over three fiscal years. The second simulation involves a reduction of government expenditure of the same magnitude as the shock to taxes. We compute that expenditure needs to be cut by 5.3 per cent in order to obtain a 2 percentage point reduction in the deficit-to-GDP ratio in three years. The expenditure shock is split among consumption, investment, and transfers according to their respective size.

Multipliers will generally be affected by the endogenous response of monetary policy to a fiscal shock as explained by Chadha and Nolan (2004). For example, an increase in VAT pushes up inflation and, if the central bank increases interest rate as a response, it will further reduce GDP and therefore increase the multiplier. To separate the monetary response, we assume in the simulations that the Bank of England does not change its policy rate in the first two years.

Figure A. 2 shows the impact on GDP and the budget balance under the two simulations. The expenditure scenario leads to a slightly larger decline in GDP after 3 years, a 1 per cent reduction in GDP as opposed to $3 / 4$ per cent for the tax scenario. Spending cuts might have a larger downside effect than implied by the historical parameters even in the recovery phase given the continued need for fiscal support as the economy adjusts to a post-pandemic allocation with differential impacts at household, sector and region level and an increased emphasis on health and 
Figure A1 3rd year cumulative fiscal multiplier

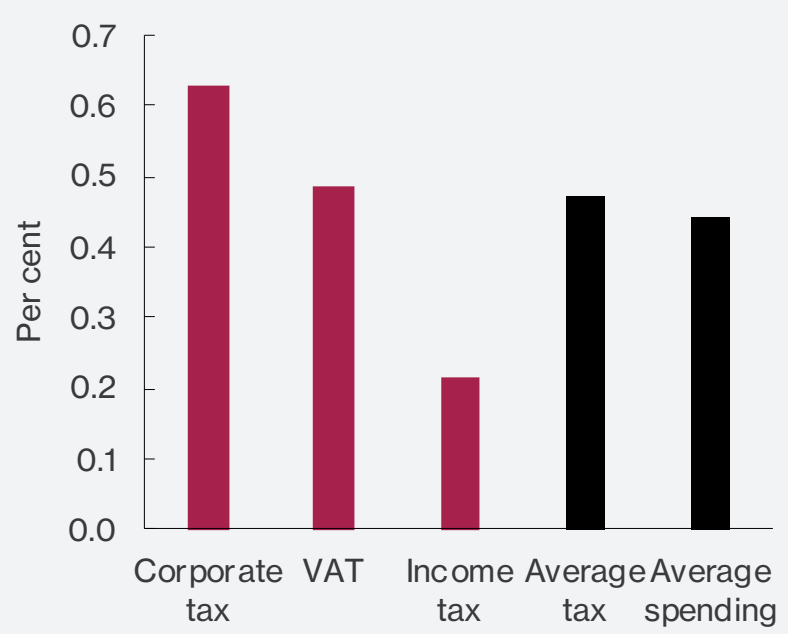

Note: Absolute value of the change in 3rd year GDP for a change in tax revenues or in spending of 1 per cent of GDP spread over 3 years. Spending shock is composed of government expenditure, investment and transfers based on historical weights. Average tax shock is calibrated so that each tax (income, VAT and corporate) brings in the same amount of additional revenue.

Source: NiGEM simulation.

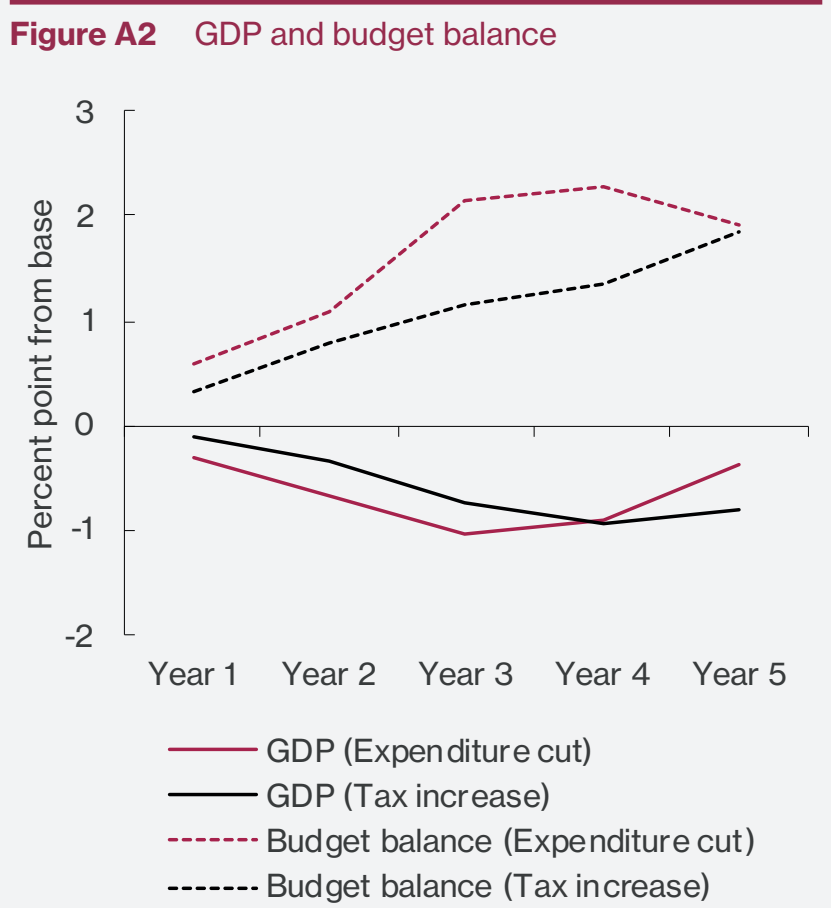

Note: The expenditure cut and the tax increase are calibrated to $2 \%$ of GDP each and introduced over 3 years. Source: NiGEM simulation.

social care. For households, the expenditure scenario is the most harmful because it reduces their transfers by over 5 per cent, which leads to a slightly larger reduction in real personal disposable income than in the tax scenario where they suffer from higher prices because of the VAT hike. The tax scenario leads to a smaller than 2 per cent of GDP improvement in the budget balance because the recessionary impact leads to a smaller tax base. In both scenarios, the unemployment rate rises by 0.6 percentage points after 4 years. Our findings are also consistent with related studies in the literature. For example, Erceg and Linde (2013) find that with limited scope for monetary accommodation, tax-based consolidation tends to have smaller adverse effects on output that expenditure-based consolidation in the near-term, though is more costly in the longer-run.

The results of our simulations suggest that a prudent approach to fiscal consolidation would favour tax rises to spending cuts because of their relatively smaller impact on GDP initially. Among the possible tax rises, income tax should be preferred because of its lower multiplier. The emphasis on tax rises is also justified by the need for increased spending on welfare, health, infrastructure and education due to the large negative shock from the pandemic. Cutting public investment and spending on social care and education would have more adverse effects on the economy's longer-term potential output through their impact on productivity. The consolidation should only start when the economy is on a clear recovery path, and even so should be done gradually in order not to harm the recovery.

\section{REFERENCES}

Canzoneri, M., Collard, F., Dellas, H., and Diba, B. (2016). 'Fiscal multipliers in recessions'. The Economic fournal, 126(590), 75-108.

Chadha, J. S. and Charles, N (2004). 'Interest rate bounds and fiscal policy,' Economics Letters, Elsevier, vol. 84(1), pages 9-15, July.

Erceg, C. J., \& Linde, J. (2013). 'Fiscal consolidation in a currency union: Spending cuts vs. tax hikes', fournal of Economic Dynamics and Control, 37(2), 422-445.

Lenoël, C. (2020) 'What is the size of the fiscal multiplier?' The Economics Observatory, https://www.economicsobservatory. com/what-size-fiscal-multiplier

Sims, E., and Wolff, J. (2017). 'State-dependent fiscal multipliers: Calvo vs. Rotemberg,' Economics Letters, 159, $190-194$. 


\section{The Budget comes at a crucial time in the fight against Covid-19.}

The Chancellor of the Exchequer will present his Budget to the House of Commons on 3 March. He is expected to announce short-term measures to continue to support the economy during the pandemic (Universal Credit, furlough and self-employed schemes). But he should in our view resist political pressures to increase taxes until the recovery is on a firmer footing. The fiscal background is a debt-to-GDP ratio which is high by modern standards but this follows two shocks of unusual magnitudes in just over a decade. His first priority should be providing the necessary fiscal support to support the public health measures required to tackle Covid-19 until the vaccination programme is successful in reducing the health threat. The second priority should be a new framework that gives us time to ride this storm and provide comfort to market participants that there is no credit or inflation risks for UK debt.

\section{There is no need to panic about the higher debt as a result of the pandemic but fiscal consolidation will require detailed planning. \\ Standard theory suggests that one-off level shocks to the debt stock or ratio should not necessarily result in fiscal adjustment but that what matters for the future path of debt are the deficit and the relationship between interest rates and growth. The government of the day may decide for other reasons - for example, because it perceives the edge of a 'fiscal cliff', or because it anticipates another large negative economic shock in the near future - that it nonetheless wishes to reduce government debt more rapidly.}

Any plan to reduce public debt should be consistent with economic and social objectives for fiscal policy (Chadha, 2020). It would arguably be too early to start a fiscal consolidation when the country is in the middle of battling the pandemic and the economy is weakened. The number of Covid-19 related daily deaths reached a peak of 1820 on 20 January 2021, and GDP in the first quarter of 2021 is forecast to be 11.6 per cent below end-2019 level. The degree of fiscal consolidation required is also uncertain at this point because we do not know the full extent of the impact of the pandemic on public finances and the economy until the pandemic is over. This should not, however, preclude the government from beginning a Comprehensive Tax Review to examine the best way to raise additional taxation should it turn out to be necessary on the basis of lasting economic damage.

The choice of an appropriate fiscal instrument is critical as debt reduction requires sequences of fiscal surpluses and nominal GDP growth. In box $A$, we present different scenarios of fiscal consolidation to compare the implications of tax rises and spending cuts once the recovery from the pandemic is on a stronger footing.

\section{Prices and monetary policy}

Inflation subdued but likely to rise through 2021 .

Inflation has remained low in recent months, largely in line with our expectations for Q4 of 2020 and Q1 of 2021, rising slightly to 0.6 per cent in December 2020. NIESR's Lockdown Weighted Consumer Prices Index 9 also strengthened in December and the gap between it and the CPIH measure has gradually diminished since the start of the pandemic.

As discussed in Section 6 we expect debt servicing to add to input costs post-Covid; this may also be accompanied by costs relating to making workplaces safe for social consumption.

Coupled with the recovery in domestic demand we expect inflation to rise during 2021, with CPI inflation reaching 1.3 per cent in Q4 and 2 per cent in 2022. Inflation then remains close to but below its 2 per cent target in each year between 2023 and 2025 (figure 1.18).

Inflation expectations implied by forward interest rates for the coming years were marginally lower in January 2021 than in October 202, but still slightly higher than before the Covid-19 pandemic (see figure 1.19).

Interest rates to remain low but positive for the medium term with asset purchases still the go-to for policymakers.

Interest rates have been maintained at 0.1 per cent and remain at that level in our main case forecast scenario until the start of 2024. The Bank of England has been consulting on the introduction of negative interest rates, with Monetary Policy Committee members clearly taking different views on their effectiveness, but at this stage we regard it as a theoretical discussion about the monetary policy toolkit available in the case of a further negative shock, rather than a sign that negative interest rates are imminent. Term Funding Schemes have given the authorities the means to pass on lower rates to parts of the economy without threatening intermediaries' margins and seemingly without unwanted side effects.

Further extensions of quantitative easing - seemingly the marginal policy instrument - at the February or March meetings of the Monetary Policy Committee are possible, though unlikely to be unanimous, given the different mood music coming from its members. There remains a tail possibility of interest rates rising more quickly than forecast due to a consumer boom driven by the savings accumulated by some households during the lockdown periods. The Governor of the Bank of England has indicated a preference for 'unwinding' asset purchases before raising interest rates. In general, it is difficult to estimate when asset purchases will be 'wound down' because of the lack of prior experience and precise estimates about what it

9 Dixon, H. (2021) 'The Lockdown Weighted inflation CPILW for December 2020' https://www.niesr.ac.uk/blog/lockdown-weighted-inflation-cpilw-december-2020 
Figure 1.18 Inflation fan chart

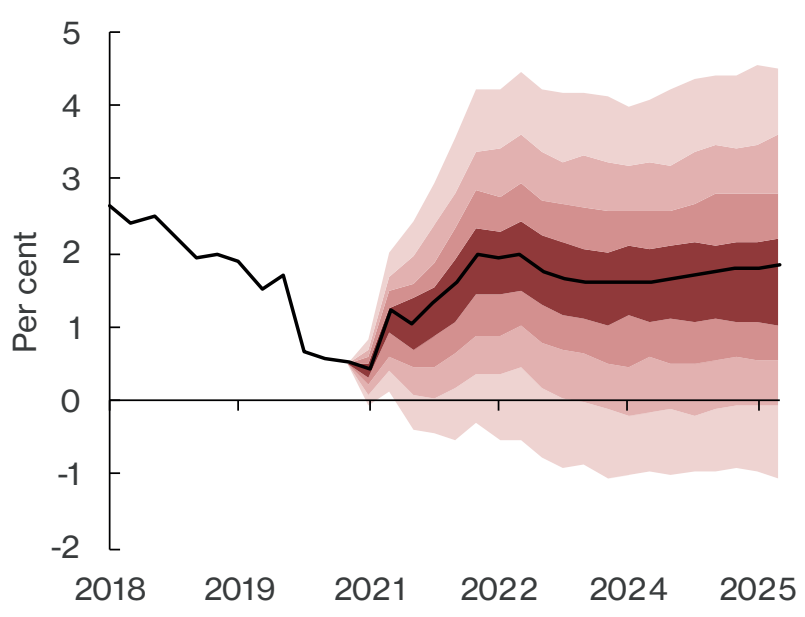

Note: The fan chart is intended to represent the uncertainty around the main-case forecast scenario shown by the black line. There is a 10 per cent chance that CPI inflation in any particular year will lie within any given shaded area in the chart. There is a 20 per cent chance that CPI inflation will lie outside the shaded area of the fan. The Bank of England's CPI inflation target is 2 per cent per annum

Source: NIESR forecast and judgement.

would do to inflation and the economy (Independent Evaluation Office, 2021).

Continued support from monetary policy, in the form of low interest rates and increased size of quantitative easing (QE) programme, contributed to lowering rates on government bonds. At the end of December 2020, the Bank of England held just under $\$ 232$ billion of the UK's public sector debt. This is 10.8 per cent of GDP of the total and is largely a result of its Term Funding Scheme loans. ${ }^{10}$ These loans are expected to be repaid at their four-year term, contributing to a decline in headline net debt after 2024-25. Turner (2021) reviews the financial stability implications of central bank balance sheet policies and highlights potential risks associated with a rise in real interest rates when central banks have large holdings of debt.

\section{REFERENCES}

Ayele, Y., Gasiorek, M., Holmes, P., Jerzewsksa, A. and Walmsley, S. (2021), 'Taking Stock of the UK-EU Trade and Cooperation Agreement: Trade in Goods,', UKTPO Briefing Paper 52 - January 2021

Bank of England, (2020), 'How has Covid affected household savings?', Bank Overground, 25 November 2020, https:// www.bankofengland.co.uk/bank-overground/2020/how-hascovid-affected-household-savings
Figure 1.19 UK instantaneous implied inflation forward curve

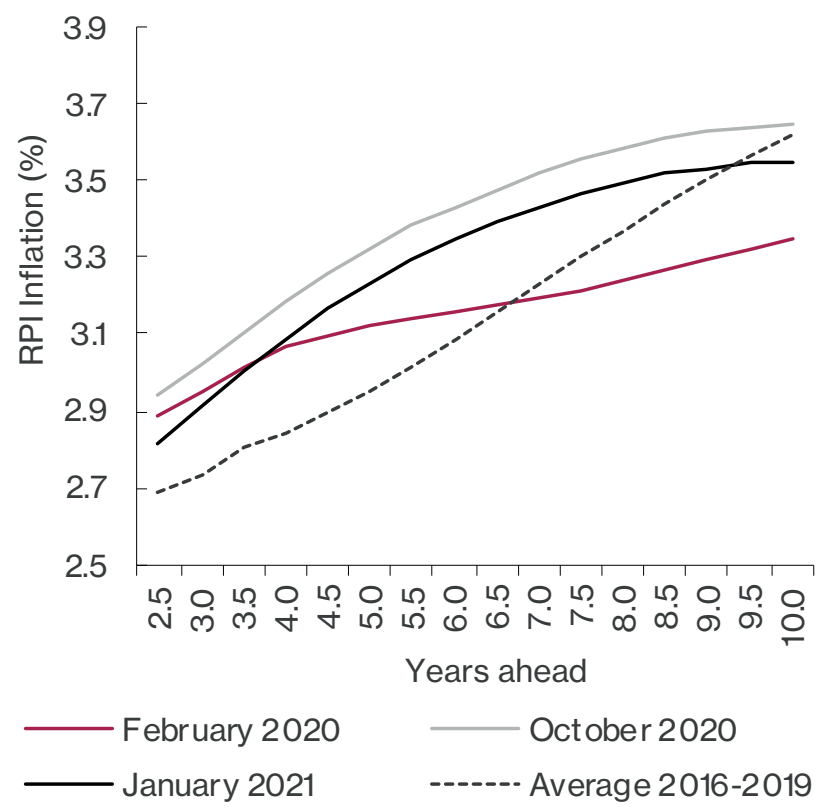

Note: RPI inflation rates derived from the gilt yield curve include an inflation risk premium related to liquidity. Source: BoE, NIESR.

Bloom, N., Bunn, P., Mizen, P., Smietanka, P. and Thwaites, G., 'The Impact of Covid-19 on Productivity,' Bank of England Staff Working Paper No. 900.

Borchert, I and Morita-Jaeger, M. (2021), 'Taking Stock of the UK-EU Trade and Cooperation Agreement: Trade in Services and Digital Trade', UKTPO Briefing Paper 53 January 2021

Chadha (2020), 'Time for the UK's 'budgetarians' to make way for some proper fiscal policy,'VoxEU, CEPR, 9 March 2020.

Chadha, J.S. (2021), 'Whither after Covid-19 and Brexit: a social science perspective', Commentary, National Institute Economic Review, February 2021.

Chadha, J.S. and Dixon, H. (2020), 'Written evidence submitted to the Treasury Committee' EIC0904, 15 December 2020, https://committees.parliament.uk/writtenevidence/18388/ html/

Hacioglu, S, Kaenzig, D. and Surico, M. (2020), 'Consumption in the time of Covid-19: Evidence from UK transaction data', CEPR Discussion Paper, No. 14733.

Hantzsche, A. and Young, G. (2019), 'The Economic Impact of Prime Minister Johnson's New Brexit Deal', National Institute Economic Review 250, November 2019.

Holland, H. and Lenoël, C. (2020), 'Fiscal measures will soften the economic blow from the coronavirus crisis', National Institute Economic Review, No. 252, F29-31, May 2020.

Independent Evaluation Office (2021), 'Evaluation of the Bank of England's approach to quantitative easing,' https://www. bankofengland.co.uk/independent-evaluation-office/ieoreport-january-2021

10 https://www.ons.gov.uk/economy/governmentpublicsectorandtaxes/publicsectorfinance/bulletins/publicsectorfinances/december2020 
Kozlowski, J., Veldkamp, L. and Venkateswaran, V. (2020), 'Scarring Body and Mind: The Long-Term Belief-Scarring Effects of COVID-19', NBER Working Paper, No. 27439.

Küçük, H, Lenoël, C. and Macqueen, R. (2020), 'UK Economic Prospects', National Institute Economic Review 254, November 2020.

Küçük, H. and Whyte, K. (2021), 'Revisions to UK Government Expenditure in the Presence of Economic Uncertainty', manuscript, NIESR .

Macqueen, R. (2020a) 'Upside and downside risks to inflation', National Institute Economic Review 253, F21-F23, August 2020.

Macqueen, R. (2020b) 'Labour market policies and productivity', National Institute Economic Review 254, F20-22, November 2020.
Macqueen, R. (2020c) 'How has wage growth varied across the UK economy during the pandemic?', Econ Observatory, 13 November 2020. https://www.economicsobservatory.com/ how-has-wage-growth-varied-across-uk-economy-duringpandemic

Malmendier, U.M and Shen, L.S (2020);'Scarred Consumption', CEPR Discussion Paper, No. 14937.

O'Connor, M. and Portes, J. (2021) 'Estimating the UK population during the pandemic' ESCoE blog https:// www.escoe.ac.uk/estimating-the-uk-population-during-thepandemic/

Turner, P. (2021), 'The New Monetary Policy Revolution: Advice and Dissent', National Institute of Economic and Social Research Occasional Papers, No. 60, forthcoming.

Van Ark, B., de Vries, K., and Erumban, A. (2020) 'How to not miss a productivity revival once again?' NIESR Discussion Paper No. 518. 